Article

\title{
Soaking in Aqueous Ammonia (SAA) Pretreatment of Whole Corn Kernels for Cellulosic Ethanol Production from the Fiber Fractions
}

\author{
Katherine L. Norvell 1 and Nhuan P. Nghiem * \\ Sustainable Biofuels and Co-Products Research Unit, Eastern Regional Research Center, Agricultural Research \\ Service, U.S. Department of Agriculture, 600 E. Mermaid Lane, Wyndmoor, PA 19038, USA; \\ knorvel@g.clemson.edu \\ * Correspondence: john.nghiem@ars.usda.gov; Tel.: +1-215-233-6753
}

Received: 4 September 2018; Accepted: 12 October 2018; Published: 16 October 2018

\begin{abstract}
Corn fiber is a co-product of commercial ethanol dry-grind plants, which is processed into distillers dried grains with solubles (DDGS) and used as animal feed, yet it holds high potential to be used as feedstock for additional ethanol production. Due to the tight structural make-up of corn fiber, a pretreatment step is necessary to make the cellulose and hemicellulose polymers in the solid fibrous matrix more accessible to the hydrolytic enzymes. A pretreatment process was developed in which whole corn kernels were soaked in aqueous solutions of 2.5, 5.0, 7.5, and $10.0 \mathrm{wt} \%$ ammonia at $105^{\circ} \mathrm{C}$ for $24 \mathrm{~h}$. The pretreated corn then was subjected to a conventional mashing procedure and subsequent ethanol fermentation using a commercial strain of natural Saccharomyces cerevisiae with addition of a commercial cellulase. Pretreatment of the corn with $7.5 \mathrm{wt} \%$ ammonia solution plus cellulase addition gave the highest ethanol production, which improved the yield in fermentation using $25 \mathrm{wt} \%$ solid from $334 \mathrm{~g}$ ethanol $/ \mathrm{kg}$ corn obtained in the control (no pretreatment and no cellulase addition) to $379 \mathrm{~g}$ ethanol $/ \mathrm{kg}$ corn (a $14 \%$ increase). The process developed can potentially be implemented in existing dry-grind ethanol facilities as a "bolt-on" process for additional ethanol production from corn fiber, and this additional ethanol can then qualify as "cellulosic ethanol" by the Environmental Protection Agency's (EPA's) Renewable Fuels Standard and thereby receive RINs (Renewable Identification Numbers).
\end{abstract}

Keywords: ethanol; corn; dry-grind process; bolt-on process; corn fiber; soaking in aqueous ammonia pretreatment; cellulase; cellulosic ethanol

\section{Introduction}

The growing demand for renewable fuels comes in response to the global crisis of relieving dependency on petroleum-based resources. Depletion of oil and other fossil fuels has shifted the focus to renewable resources to assist in the demand for fuel production. Fossil fuels account for approximately $80 \%$ of the world's energy consumption; another $12 \%$ comes from renewable resources, with biomass-derived fuels accounting for half of that amount [1,2]. Ethanol is the first liquid biofuel that reached commercialization. The two countries with the largest annual ethanol production are the United States and Brazil. The two main feedstocks used for first-generation ethanol production are corn in the United States and sugarcane in Brazil. The increasing demand for ethanol and the food-versus-fuel controversy led to the development of technology for production of second-generation ethanol, which uses lignocellulosic biomass, or simply biomass, as feedstocks.

Corn starch is the primary feedstock used in the production of ethanol in the United States. In 2016, ethanol produced from corn starch accounted for 95\% of all biofuel production. However, 
ethanol only accounts for about $10 \%$ of the total gasoline fuel consumption in the United States [2]. Developing methods to increase ethanol yield are being studied to assist in the progression of the fuel industry from fossil fuels to renewable fuels.

Corn fiber makes up about $9 \%$ of the composition of the corn kernel on a dry basis [3]. This fiber is comprised of lignocellulose material that acts as the structural make-up of the pericarp, or outer kernel covering, and the cell wall of the endosperm [4]. This aspect of the kernel consists of $18 \%$ cellulose, $35 \%$ hemicellulose, and $20 \%$ starch [5]. Corn fiber has potential to be utilized to produce additional starch-based ethanol as well as cellulosic ethanol, but the rigid, tightly packed structural composition poses a problem for accessibility to the non-starch polysaccharides for enzymatic hydrolysis into the fermentable sugars glucose and xylose [4]. With modification to the structure of corn fiber, this fraction of the corn kernel has potential to be utilized in a more economical way. Thus, developing a process in which the corn fiber is converted to fermentable sugars is needed.

In 2005, the United States Environmental Protection Agency (EPA) introduced the Renewable Fuel Standard (RFS). Each year, the RFS sets a statutory requirement mandate for volume of renewable fuels produced. The end of the 2016 marketing year saw production of 0.16 billion gallons of cellulosic ethanol [6], which was significantly below the RFS set mandate of 4.5 billion gallons [7]. The potential for additional ethanol production from corn fiber would not only help achieve the RFS standard, but would also give corn ethanol producers the opportunity to qualify their product for cellulosic or advanced biofuel status, which carries financial incentives determined by the Renewable Identification Numbers (RINs) as defined in the RFS [8]. Renewable fuel producers must meet individual fuel volume requirements by acquiring RINs, which have unique values assigned to each gallon of renewable fuel generated [9]. Existing dry-grind ethanol plants that produce additional ethanol from corn fibers would acquire RIN credits for conventional biofuel as well as for cellulosic biofuel [10].

Pretreatment methods have been studied to determine the most effective way to disrupt the structure of the non-starch polysaccharides found in cellulosic biomass [11,12]. Alkali pretreatment, which results in partial lignin removal and subsequent disruption of the cellulose and hemicellulose structures, allows access of enzymes for hydrolysis of the polysaccharides into glucose and xylose for fermentation to ethanol. Among the various alkaline pretreatment methods that have been investigated, soaking in aqueous ammonia (SAA) is a relatively low cost, high conversion efficiency method for biomass pretreatment [13]. This pretreatment method has been successfully applied to corn fibers $[14,15]$. The SAA is a batch process that can be easily implemented in dry-grind ethanol facilities by "bolting-on" to the already existing facility structure. The use of a bolt-on process for production of ethanol from corn fibers in an existing plant bears similarity to the integration of ethanol production from bagasse into an existing ethanol plant using sugarcane juice as feedstock [16].

Approximately $90 \%$ of total ethanol yield in the United States is produced from dry-grind ethanol facilities [7]. Dry-grind ethanol plants reduce capital cost by milling the entire kernel as opposed to fractionating the corn prior to processing, as is the case for wet milling [17]. Existing dry-grind plants only convert the starch fraction of corn to ethanol. The remaining non-starch fractions, which include the proteins and fibers, can be processed and dried as distiller's dried grains with solubles (DDGS). This co-product is primarily sold as high-protein animal feed, and while there is a market for this product, there is a larger demand for increased ethanol yields [18]. Dry-grind ethanol plants can be modified to produce a higher yield of conventional ethanol as well as cellulosic ethanol by adding a "bolt-on" process that converts corn fiber to fermentable sugars. Two "bolt-on" processes have been developed and implemented in existing dry-grind corn ethanol plants in the United States. These processes, which are known as the D3Max process and the Cellerate process, use steam and dilute acid pretreatment of the fiber fractions to generate additional ethanol from the cellulosic components of the corn kernel $[19,20]$. In the present study, we investigated a "bolt-on" process that used SAA, a completely different pretreatment method. 


\section{Materials and Methods}

\subsection{Materials}

Whole kernel corn was purchased from Tractor Supply Co. (Harleysville, PA, USA). The corn was hand-cleaned of debris and broken pieces and stored at $4{ }^{\circ} \mathrm{C}$ prior to processing.

The enzymes were kindly provided by DuPont Industrial Biosciences (Palo Alto, CA, USA), which included Spezyme ${ }^{\circledR}$ Extra (reported activity of 14,000 $\alpha$-amylase (AA) units per g), Fermenzyme ${ }^{\circledR}$ L-400 (reported activity of 350 glucoamylase (GA) units per g) and Accellerase ${ }^{\circledR} 1500$ (reported endoglucanase activity of 2200-2800 carboxymethylcellulose (CMC) units per g and $\beta$-glucosidase activity of 525-775 para-nitrophenyl- $\beta$-D-glucopyranoside (pNPG) units per $\mathrm{g}$ ).

The microorganism used for ethanol fermentation was Red Star Saccharomyces cerevisiae yeast strain purchased from Lesaffre Yeast Corporation (Milwaukee, WI, USA). The dried yeast was stored at $4{ }^{\circ} \mathrm{C}$.

The concentrated ammonium hydroxide solution (28-30 wt\%) was purchased from J.T.Baker ${ }^{\circledR}$ (Center Valley, PA, USA). Other chemicals were purchased from various suppliers and were of reagent grade.

\subsection{Methods}

\subsubsection{Pretreatment of Corn Kernels}

Approximately $300 \mathrm{~g}$ (260 g dry mass) of whole corn was soaked in $300 \mathrm{~mL}$ of ammonium hydroxide solution having ammonia contents of $2.5,5,7.5$, and $10 \mathrm{wt} \%$ in $1000-\mathrm{mL}$ glass screw-cap bottles. The ammonium hydroxide solutions were prepared by dilution of the purchased concentrated solution with appropriate amounts of deionized (DI) water. The bottles containing the corn/ammonium hydroxide mixtures were placed in an oven set at $105^{\circ} \mathrm{C}$ for $24 \mathrm{~h}$. These conditions were selected based on the results obtained in previous studies on pretreatment of various biomass sources $[14,15,21]$. After the pretreatment period, the liquids were filtered off and the pretreated corn rinsed with DI water until the wash water was clear. The filtrate and wash water were collected, and the pretreated corn left in a fume hood at ambient temperature (about $25^{\circ} \mathrm{C}$ ) until no ammonia odor was detected. The filtrate and wash water were combined and $50 \mathrm{~mL}$ was used to determine the total solid content, which subsequently was used to calculate the loss of mass from the corn during the pretreatment.

\subsubsection{Ethanol Fermentation}

Corn mashing: The pretreated corn was air-dried at ambient temperature overnight (about $16 \mathrm{~h}$ ) before it was used in the ethanol fermentation experiments. The moisture content of the pretreated corn was determined (see the analytical section below) and used to calculate the quantity needed to prepare a $25 \mathrm{wt} \%$ corn mash (dry basis). The pretreated corn was ground using a Krups Type 203 coffee grinder (Parsippany, NJ, USA). The ground corn was transferred to a stainless-steel beaker and brought to $25 \mathrm{wt} \%$ solids using DI water. The beaker was placed in an oil bath and its content were vigorously mixed with a mechanical agitator. The $\mathrm{pH}$ of the mash was adjusted to 5.6 with $2 \mathrm{~N} \mathrm{H}_{2} \mathrm{SO}_{4}$ and Spezyme Extra (a thermostable starch hydrolyzing $\alpha$-amylase) was added at $0.3 \mathrm{~g} / \mathrm{kg}$ dry solids. The mash was maintained at $60^{\circ} \mathrm{C}$ for $2 \mathrm{~h}$, then the temperature increased to $90{ }^{\circ} \mathrm{C}$ and maintained for $1 \mathrm{~h}$. DI water was added intermittently during the corn liquefaction to account for loss of water due to evaporation. The beaker was then removed from the oil bath and weighed. DI water was added as necessary to bring the mash back to $25 \mathrm{wt} \%$ solids. The beaker was placed in an ice bath and allowed to cool to approximately $55^{\circ} \mathrm{C}$.

Ethanol fermentation: The $\mathrm{pH}$ of the cooled mash was adjusted to 4.0 using $2 \mathrm{~N} \mathrm{H}_{2} \mathrm{SO}_{4}$ before it was split into two approximately equal batches. Fermenzyme L-400 (a glucoamylase and protease mix) was added to both batches at $0.65 \mathrm{~g} / \mathrm{kg}$ dry solids. Accellerase 1500 (cellulase) then was added to 
only one batch at $0.25 \mathrm{~g} / \mathrm{g}$ dry solids. Each batch was thoroughly mixed and then distributed evenly into six $250-\mathrm{mL}$ shaker flasks. A $5 \mathrm{wt} \%$ yeast slurry was prepared in DI water and stirred at ambient temperature for about $30 \mathrm{~min}$. The rehydrated yeast slurry then was added to the flasks at $0.25 \mathrm{~mL}$ solution per $50 \mathrm{~g}$ mash. The flasks were corked with rubber stoppers punctured by small hypodermic needles for release of $\mathrm{CO}_{2}$. The flasks were incubated at $32{ }^{\circ} \mathrm{C}$ and $200 \mathrm{rpm}$ for $72 \mathrm{~h}$. Weight loss due to $\mathrm{CO}_{2}$ production was determined by weighing the flasks at intervals. Since the production of $\mathrm{CO}_{2}$ was proportional to the production of ethanol (one mole $\mathrm{CO}_{2} / \mathrm{mole}$ ethanol), the use of weight loss allowed direct monitoring of the progress of ethanol fermentation without requiring the flasks to be opened for sampling, which might cause loss of ethanol due to its volatility. At the end of the fermentation, samples were taken and centrifuged at 13,200 rpm for 3 min (Eppendorf model 5415D, Hauppauge, NY, USA) The supernatant was filtered through 0.2 micron filters and used for HPLC analysis.

In a separate experiment using corn treated with $7.5 \mathrm{wt} \%$ ammonia and with Accellerase 1500 addition, urea was also added to the mash at $0.4 \mathrm{~g} / \mathrm{kg}$ mash. This experiment was performed to study the effect of an additional nitrogen source (urea) on the fermentation efficiency.

Experiments using untreated corn were performed in the same manner without and with addition of Accellerase 1500. Urea was added at $0.4 \mathrm{~g} / \mathrm{kg}$ mash in both experiments. The results obtained in the experiment using untreated corn and without Accellerase 1500 addition were used as the baseline for a commercial dry-grind ethanol process.

The key steps of the experimental procedure are shown in detail in Figure 1.

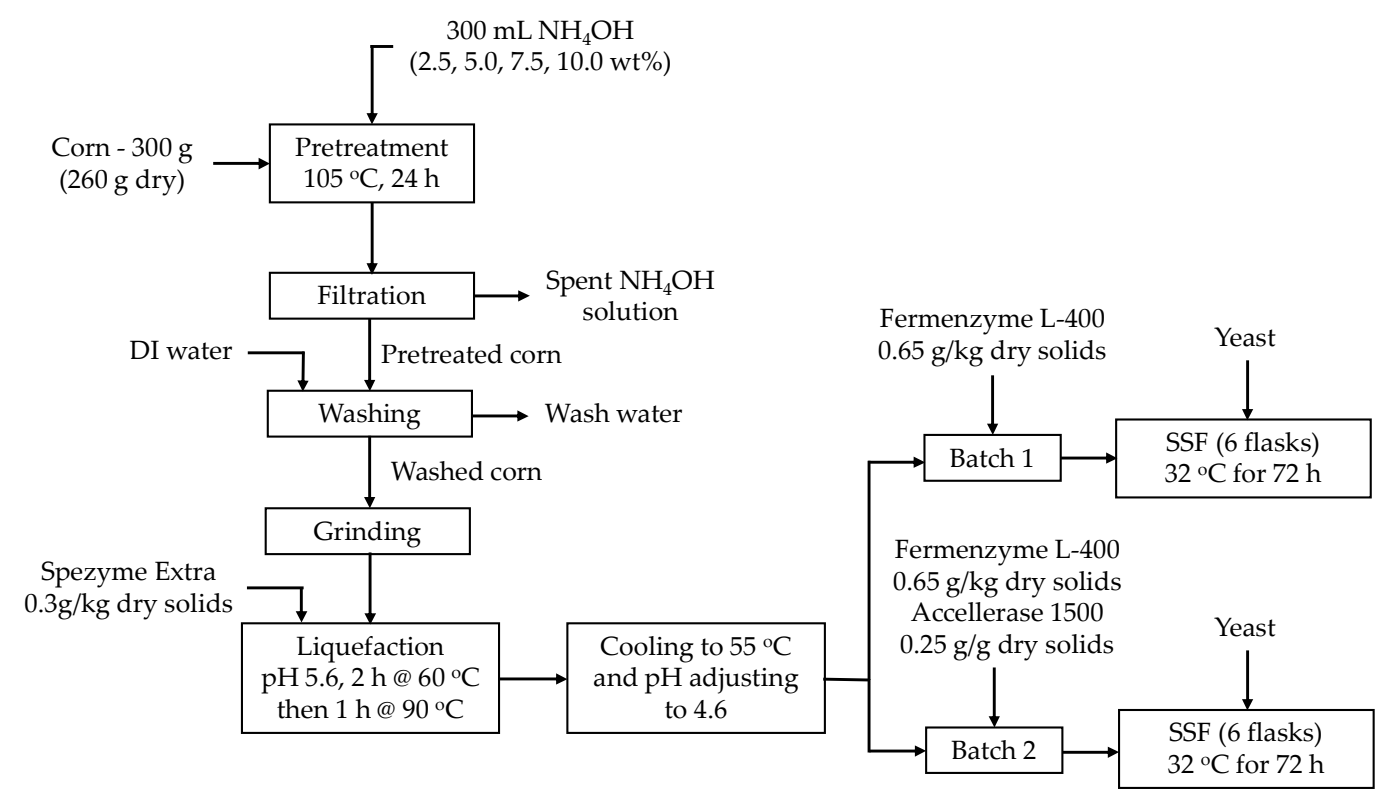

Figure 1. Schematic diagram of the experimental procedure including soaking in aqueous ammonia (SAA) pretreatment and subsequent ethanol fermentation. $\mathrm{DI}=$ deionized. SSF $=$ Simultaneous saccharification and fermentation.

\subsubsection{Analytical Methods}

The starch content of the untreated corn was determined by the modified Megazyme total starch assay procedure (amyloglucosidase / $\alpha$-amylase method) [22]. The ground corn samples were analyzed in triplicate. The average starch content of the untreated corn was determined to be $67.97 \mathrm{wt} \%$ on a dry basis.

To determine the composition of the corn fiber, the ground corn was first subjected to starch removal. Thus, a mash of $1000 \mathrm{~g}$ total weight at $5 \mathrm{wt} \%$ dry solids was prepared. Spezyme Extra and Fermenzyme L-400 were added at $5 \times$ the dosages described in the preparation of the ethanol fermentation corn mash previously (Section 2.2.2). The mixture was placed in a 2-L flask, which was incubated at $55^{\circ} \mathrm{C}$ and $250 \mathrm{rpm}$ overnight (about $16 \mathrm{~h}$ ). The solids were collected by centrifugation, 
washed three times with DI water, and dried in a $130^{\circ} \mathrm{C}$ oven. The dried solids then were subjected to the compositional analysis procedure developed by the National Renewable Energy Laboratory (NREL) in Golden, Colorado, USA [23]. The composition of the de-starched corn fiber is shown in Table 1.

Table 1. Composition of the de-starched corn fiber.

\begin{tabular}{cc}
\hline Component & Content $\mathbf{( w t} \%$, Dry Basis) \\
\hline Glucan & $17.51 \pm 0.47$ \\
Xylan & $14.00 \pm 0.46$ \\
Arabinan & $8.65 \pm 0.32$ \\
Lignin & $20.09 \pm 0.15$ \\
Ash & $0.16 \pm 0.02$ \\
\hline
\end{tabular}

The total solid contents of the combined ammonia solution filtrate and wash water obtained during the pretreatment of corn were determined by placing a pre-weighed 50-mL sample in an oven set at $105^{\circ} \mathrm{C}$ for $24 \mathrm{~h}$. The weights of the dried solids then were determined and the total solid contents calculated.

The moisture content of the untreated and treated corn was determined by drying about 3-5 g of material in a moisture balance (model MB45, Ohaus, Parsippany, NJ, USA).

Fermentation samples were analyzed for ethanol by HPLC. The HPLC was an Agilent 1200 series utilizing the Bio-Rad Aminex HPX-87H column (Hercules, CA, USA). Analysis conditions were as follows: $65{ }^{\circ} \mathrm{C}$ column temperature with $0.6 \mathrm{~mL} / \mathrm{min}$ flow rate of $5 \mathrm{mM} \mathrm{H}_{2} \mathrm{SO}_{4}$ solvent.

\section{Results}

\subsection{Aqueous Ammonia Treatment of Corn}

The results of mass loss during aqueous ammonia treatment of the whole corn kernels are summarized in Table 2. The mass loss increased when the ammonia concentration was increased but subsequently leveled off after the ammonia concentration reached $7.5 \mathrm{wt} \%$. Ammonia normally does not cause degradation of starch and has been used extensively in preservation of corn in silo storage. In fact, ammonia was found to reduce the rates of microbial starch degradation due to its anti-microbial activity [24]. In aqueous ammonia pretreatment of corn fiber and other lignocellulosic materials, lignin was extensively removed whereas high degrees of preservation of structural carbohydrates, in particular glucan, were observed. The production rates and yields of fermentable sugars by subsequent enzymatic hydrolysis of the pretreated materials were significantly increased $[15,21]$. In the present study, the highest mass loss, which was observed at 7.5 and $10 \mathrm{wt} \%$ ammonia, was only $5.4 \mathrm{wt} \%$ of the original mass.

Table 2. Mass loss during aqueous ammonia pretreatment of corn.

\begin{tabular}{ccccc}
\hline Concentration of $\mathrm{NH}_{\mathbf{4}} \mathrm{OH}$ Solution (wt\%) & $\mathbf{2 . 5}$ & $\mathbf{5}$ & $\mathbf{7 . 5}$ & $\mathbf{1 0}$ \\
\hline Mass of starting corn (g dry basis) & 263.43 & 260.40 & 260.66 & 260.48 \\
Mass of treated corn after washing (g dry basis) & 256.46 & 252.42 & 246.65 & 246.47 \\
Mass loss (\% of original mass) & 2.65 & 3.06 & 5.37 & 5.38 \\
\hline
\end{tabular}

\subsection{Ethanol Fermentation}

To illustrate the progress of ethanol fermentation, the weight loss due to $\mathrm{CO}_{2}$ production obtained in the experiment using corn treated by $7.5 \mathrm{wt} \%$ ammonia solution and with addition of cellulase at the start of the fermentation is plotted against time in Figure 2. The rate of ethanol production, which was directly related to the rate of $\mathrm{CO}_{2}$ production, was very high initially. Ethanol production gradually slowed down and eventually stopped due to exhaustion of substrate as well as ethanol inhibition. 
The progress of fermentation in other experiments followed similar trends. The curve shown in Figure 2 clearly indicates that the fermentation was completed at $72 \mathrm{~h}$. Based on this observation, all fermentation experiments were terminated and final samples were taken at $72 \mathrm{~h}$, as mentioned previously in Section 2.2.2.

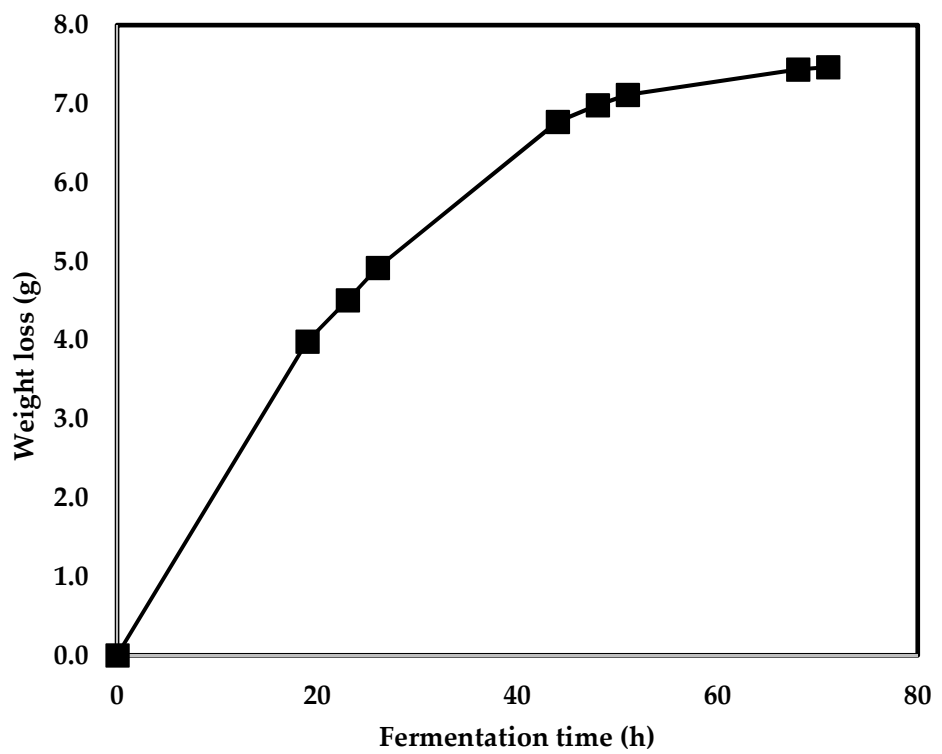

Figure 2. Weight loss due to production of $\mathrm{CO}_{2}$ in fermentation experiment using corn treated with $7.5 \mathrm{wt} \%$ ammonia solution and with addition of cellulase before start of the SSF. Note: Average values were used in the graph. The error bars were imbedded within the symbols.

The final ethanol concentrations and the calculated yields are summarized in Table 3. To account for the effect of mass loss during pretreatment and to allow for a more realistic comparison from a process standpoint, the yields were re-calculated on the basis of $\mathrm{g}$ ethanol produced per $\mathrm{kg}$ raw (untreated) corn and are shown in the last column.

Table 3. Final ethanol concentrations and calculated yields in control experiment and experiments using aqueous ammonia-treated corn.

\begin{tabular}{|c|c|c|c|}
\hline Experiment & $\begin{array}{c}\text { Final Ethanol } \\
\text { Concentration }(\mathrm{g} / \mathrm{L})\end{array}$ & $\begin{array}{c}\text { Yield } \\
\text { (g Ethanol/kg Treated Corn) }\end{array}$ & $\begin{array}{c}\text { Yield } \\
\text { (g Ethanol/kg Raw Corn) }\end{array}$ \\
\hline $\begin{array}{l}\text { Corn treated with } 2.5 \mathrm{wt} \% \\
\text { ammonia without cellulase }\end{array}$ & $103.91 \pm 1.05$ & $349.9 \pm 3.1$ & $340.7 \pm 3.0$ \\
\hline $\begin{array}{l}\text { Corn treated with } 2.5 \mathrm{wt} \% \\
\text { ammonia with cellulase }\end{array}$ & $106.31 \pm 0.76$ & $359.3 \pm 2.2$ & $349.7 \pm 2.2$ \\
\hline $\begin{array}{l}\text { Corn treated with } 5 \mathrm{wt} \% \text { ammonia } \\
\text { without cellulase }\end{array}$ & $108.79 \pm 0.24$ & $369.0 \pm 0.7$ & $357.7 \pm 0.7$ \\
\hline $\begin{array}{l}\text { Corn treated with } 5 \mathrm{wt} \% \text { ammonia } \\
\text { with cellulase }\end{array}$ & $110.83 \pm 0.58$ & $377.0 \pm 1.7$ & $365.5 \pm 1.6$ \\
\hline $\begin{array}{l}\text { Corn treated with } 7.5 \mathrm{wt} \% \\
\text { ammonia without cellulase }\end{array}$ & $112.16 \pm 1.40$ & $382.3 \pm 4.1$ & $361.7 \pm 3.9$ \\
\hline $\begin{array}{l}\text { Corn treated with } 7.5 \mathrm{wt} \% \\
\text { ammonia with cellulase }\end{array}$ & $116.84 \pm 0.36$ & $401.0 \pm 1.1$ & $379.5 \pm 1.0$ \\
\hline $\begin{array}{l}\text { Corn treated with } 7.5 \mathrm{wt} \% \\
\text { ammonia with cellulase plus urea }\end{array}$ & $114.69 \pm 1.0$ & $392.4 \pm 3.7$ & $371.3 \pm 3.5$ \\
\hline $\begin{array}{l}\text { Corn treated with } 10 \mathrm{wt} \% \\
\text { ammonia without cellulase }\end{array}$ & $104.86 \pm 0.36$ & $353.6 \pm 2.9$ & $334.6 \pm 2.8$ \\
\hline $\begin{array}{l}\text { Corn treated with } 10 \mathrm{wt} \% \\
\text { ammonia with cellulase }\end{array}$ & $112.98 \pm 0.54$ & $385.6 \pm 1.1$ & $364.8 \pm 1.0$ \\
\hline Untreated corn without cellulase & $99.84 \pm 1.67$ & & $334.2 \pm 1.6$ \\
\hline Untreated corn with cellulase & $102.64 \pm 1.25$ & & $345.0 \pm 4.9$ \\
\hline
\end{tabular}


The results obtained with and without cellulase addition in each set of experiment (no pretreatment, $2.5 \mathrm{wt} \%$ ammonia, $5 \mathrm{wt} \%$ ammonia, $7.5 \mathrm{wt} \%$ ammonia, $10 \mathrm{wt} \%$ ammonia) were compared using the $t$-test. The $p$ values in all cases were $<0.001$, which indicated statistically significant differences between no cellulase and cellulase addition. The results obtained with pretreated corn using various ammonia concentrations and cellulase addition were also compared to the result obtained in the base case (no pretreatment and no cellulase addition) using the $t$-test. The $p$ values obtained were all $<0.001$, which indicated the improvements obtained with pretreatment and cellulase addition over the base case were statistically significant.

The SAA pretreatment combined with cellulase addition clearly gave improvement of ethanol yield over the baseline. The relationship between ammonia concentration in the SAA pretreatment and ethanol yield improvement is shown in Figure 3. Improvement of ethanol yield over the baseline increased with increasing ammonia concentration and reached the highest level of $13.6 \%$ when $7.5 \mathrm{wt} \%$ ammonia was used, before it declined when $10 \mathrm{wt} \%$ ammonia was used in the pretreatment. Thus, $7.5 \mathrm{wt} \%$ could be selected as the optimum ammonia concentration in the SAA pretreatment of whole corn kernels.

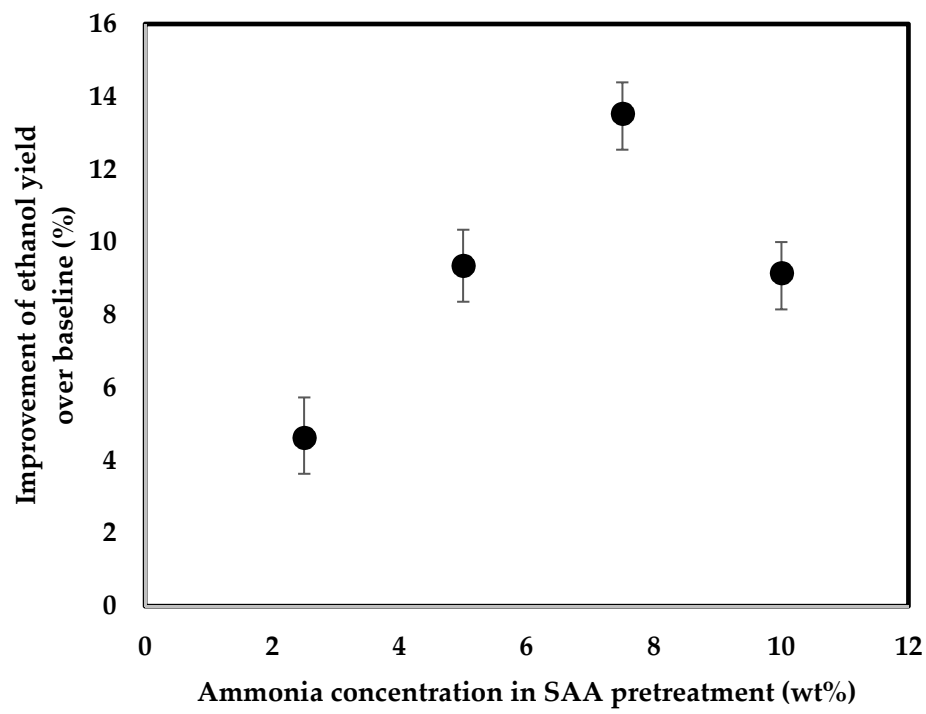

Figure 3. The relationship between ammonia concentrations used in the SAA pretreatment and improvement of ethanol yield with cellulase addition over the baseline value.

The results in Table 3 also indicate the beneficial effect of cellulase addition on ethanol yield. For example, in the case of $7.5 \mathrm{wt} \%$ ammonia pretreatment, the improvement of ethanol yield without cellulase addition over the baseline was $8.2 \%$, which was only about $60 \%$ of the improvement when cellulase was added (13.6\%). In the case of the untreated corn, addition of cellulase also resulted in higher ethanol yield. The improvement in this case, however, was relatively modest at $3.2 \%$. The cellulase formulation used in the present study, in addition to its main function of glucose production via cellulose hydrolysis, also has been observed for its high viscosity reduction capability (qualitative observation in the corresponding author's laboratory; unpublished results.) In the case of the untreated corn, very low glucose production from the corn fiber fraction was expected. The increase in ethanol yield, therefore, probably was due mainly to viscosity reduction, which assisted in better distribution of enzymes, nutrients, and yeast during the fermentation. Another special characteristic of the cellulase used in the present study is it is a whole broth product that is high in residual nutrients carried over from the manufacturing process [25]. It can be seen in Table 3 that no improvement of ethanol yield was observed when a urea dosage of $0.4 \mathrm{~g} / \mathrm{kg}$, which was the level normally used in a dry-grind corn ethanol process, was added to the mash prepared with $7.5 \mathrm{wt} \%$ ammonia-treated corn with cellulase addition. This observation indicated that the nutrients in Accelerase 1500 were sufficient to allow ethanol fermentation to proceed at high efficiencies. 


\section{Discussion}

A process has been developed for production of ethanol from corn fiber in addition to ethanol produced from corn starch in a conventional dry-grind process. In the newly developed process, whole corn kernels were pretreated in an aqueous ammonia solution. Following removal of residual ammonia in a washing step, the pretreated corn then was subjected to mashing and ethanol fermentation where a commercial cellulase was added to generate glucose from the glucan fraction of the corn fiber. The fiber-derived glucose was fermented to produce additional ethanol. The optimum ammonia concentration was determined to be $7.5 \mathrm{wt} \%$. Ammonia is easy to recover and recycle due to its high volatility. Processes for ammonia recovery and re-use in lignocellulosic biomass pretreatment have been suggested [26]. The relatively low concentration of ammonia required in the pretreatment solution will facilitate easy regeneration of such solutions. Since the newly developed process does not require complex and expensive equipment, it has strong potential to be added to an existing dry-grind corn ethanol plant as a "bolt-on" process. The improvement of ethanol yield over the baseline value obtained in the new ammonia-based process compared favorably to other "bolt-on" processes that has been practiced commercially. Under optimum conditions, the ethanol yield improvement over the baseline value obtained in the ammonia-based process was $13.6 \%$, which is higher than the values obtained in the D3Max process (11\%) [19] and the Cellerate process (6\%) [20].

Since the yeast that was used in the present study was a natural strain, the additional ethanol produced only came from the glucose derived from hydrolysis of the glucan fraction of the corn fiber. Although Accellerase 1500 contains both cellulase and xylanase activities, the highly complex structure of the hemicellulose in corn fiber severely restricts release of xylose by enzymatic hydrolysis [14]. It has been demonstrated that to obtain high yields of both glucose and xylose, sequential enzymatic and dilute sulfuric hydrolysis of corn fiber are needed [15]. To improve ethanol yield in the ammonia-based process demonstrated in the present study, future investigation should include combined enzymatic and dilute acid hydrolysis of the SAA-treated corn and the use of strains capable of fermenting both glucose and xylose at high efficiencies.

\section{Conclusions}

A simple pretreatment process employing soaking in aqueous ammonia of whole corn kernels has been demonstrated. When the pretreated corn was used in a typical dry-grind process with addition of a commercial cellulase, significant improvements of ethanol yield over the baseline value were observed. Although the newly developed process has strong potential for implementation as a "bolt-on" process in an existing dry-grind corn ethanol plant, further development is still needed. It is highly recommended that future efforts should include not only yield improvement but also experimentation at pilot or semi-commercial scales.

Author Contributions: K.L.N. and N.P.N. contributed to the concept development, design of experiments, analysis of results, and preparation of the manuscript. K.L.N. performed the majority of the experiments.

Funding: This research received no external funding.

Acknowledgments: The assistance provided by Gerard Senske, Jennifer Thomas, and Matthew Toht is sincerely appreciated.

Conflicts of Interest: The authors declare no conflict of interest.

\section{References}

1. U.S. Energy Facts Explained. U.S. Energy Information Administration. Available online: https://www.eia. gov / energyexplained/?page=us_energy_home (accessed on 8 August 2018).

2. U.S. Bioenergy Statistics. United States Department of Agriculture Economic Research Service. Available online: https: / /www.ers.usda.gov/data-products/us-bioenergy-statistics (accessed on 8 August 2018). 
3. Typical Composition of Yellow Dent Corn. Available online: https://www.bungeservices.com/irj/go/ km/docs/documents/Public\%20Documents/millingSite/Documents\%20and\%20Forms/Attachments/ Corn\%20Milling\%20Process.pdf (accessed on 8 August 2018).

4. Kim, D.; Orrego, D.; Ximenes, E.; Ladisch, M. Cellulose conversion of corn pericarp without pretreatment. Bioresour. Technol. 2017, 245, 511-517. [CrossRef] [PubMed]

5. Gaspar, M.; Kalman, G.; Reczey, K. Corn fiber as a raw material for hemicellulose and ethanol production. Process Biochem. 2007, 42, 1135-1139. [CrossRef]

6. Lynd, L. The grand challenge of cellulosic biofuels. Nat. Biotechnol. 2017, 35, 912-915. [CrossRef] [PubMed]

7. 2017 Ethanol Industry Outlook. Renewable Fuels Association. Available online: http:/ /www.ethanolrfa. org/wp-content/uploads/2017/02/Ethanol-Industry-Outlook-2017.pdf (accessed on 9 August 2018).

8. Biotechnology Industry Organization. The value proposition for cellulosic and advanced biofuels under the US federal renewable fuel standard. Ind. Biotechnol. 2011, 7, 111-117. [CrossRef]

9. McPhail, L.; Westcott, P.; Lutman, H. The Renewable Identification Number System and U.S. Biofuel Mandates. United States Department of Agriculture. Available online: http:/ / usda.mannlib.cornell.edu/ usda/ers/BioEnergy/2010s/2011/BioEnergy-11-08-2011.pdf (accessed on 9 August 2018).

10. Renewable Fuel Standard Program Regulatory Impact Analysis. United States Environmental Protection Agency. Available online: https:/ / www.epa.gov/sites/production/files/2015-08/documents / 420r07004. pdf (accessed on 9 August 2018).

11. Rastogi, M.; Shrivastava, S. Recent advances in second generation bioethanol production: An insight to pretreatment, saccharification and fermentation processes. Renew. Sustain. Energy Rev. 2017, 80, 330-340. [CrossRef]

12. Maurya, D.; Singla, A.; Negi, S. An overview of key pretreatment processes for biological conversion of lignocellulosic biomass to bioethanol. 3 Biotech 2015, 5, 597-609. [CrossRef] [PubMed]

13. Gupta, R.; Kim, T.H.; Lee, Y.Y. Substrate dependency and effect of xylanase supplementation on enzymatic hydrolysis of ammonia-treated biomass. Appl. Biochem. Biotechnol. 2008, 148, 59-70. [CrossRef] [PubMed]

14. Nghiem, N.P.; Montanti, J.; Johnston, D.; Drapcho, C. Fractionation of corn fiber treated by soaking in aqueous ammonia (SAA) for isolation of hemicellulose B and production of C5 sugars by enzyme hydrolysis. Appl. Biochem. Biotechnol. 2011, 164, 1390-1404. [CrossRef] [PubMed]

15. Nghiem, N.P.; Montanti, J.; Kim, T.H. Pretreatment of dried distillers grains with solubles by soaking in aqueous ammonia and subsequent enzymatic/dilute acid hydrolysis to produce fermentable sugars. Appl. Biochem. Biotechnol. 2016, 179, 237-250. [CrossRef] [PubMed]

16. Dias, M.O.S.; Junqueria, T.L.; Cavalett, O.; Cunha, M.P.; Jesus, C.D.F.; Rossell, C.E.V.; Filho, R.M.; Bonomi, A. Integrated versus stand-alone second generation ethanol production from sugarcane bagasse and trash. Bioresour. Technol. 2012, 103, 152-161. [CrossRef] [PubMed]

17. Drapcho, C.M.; Nghiem, N.P.; Walker, T.H. Biofuels Engineering Process Technology, 1st ed.; McGraw-Hill: New York, NY, USA, 2008; pp. 105-174, ISBN 978-0-07-148749-8.

18. A Guide to Distiller's Dried Grains with Solubles. U.S. Grains Council. Available online: https://ethanolrfa. org/wp-content/uploads/2015/11/2012_DDGS_Handbook-1.pdf (accessed on 9 August 2018).

19. Advantages of D3Max. Available online: https://www.d3maxllc.com/d3max-advantages (accessed on 24 August 2018).

20. Quad County Corn Processors. Available online: https://ethanol.org/Delayne\%20Johnson\%20Quiet\% 20Ingenuity.pdf (accessed on 24 August 2018).

21. Kim, T.H.; Nghiem, N.P.; Hicks, K.B. Pretreatment and fractionation of corn stover by soaking in ethanol and aqueous ammonia. Appl. Biochem. Biotechnol. 2009, 153, 171-179. [CrossRef] [PubMed]

22. Megazyme Total Starch Assay Procedure. Available online: https://secure.megazyme.com/files/Booklet/ K-TSTA_DATA.pdf (accessed on 10 August 2018).

23. Sluiter, A.; Hames, B.; Ruiz, R.; Scarlata, C.; Sluiter, J.; Templeton, D.; Crocker, D. Determination of Structural Carbohydrates and Lignin in Biomass. Available online: https://www.nrel.gov/docs/gen/fy13/42618.pdf (accessed on 10 August 2018).

24. Srivastava, V.K.; Mowat, D.N. Preservation and processing of whole high moisture shelled corn with ammonia. Can. J. Anim. Sci. 1980, 60, 683-688. [CrossRef] 
25. Accellerase ${ }^{\circledR 1500: ~ C e l l u l a s e ~ E n z y m e ~ C o m p l e x ~ f o r ~ L i g n o c e l l u l o s i c ~ B i o m a s s ~ H y d r o l y s i s . ~ A v a i l a b l e ~ o n l i n e: ~}$ http:/ / www.shinshu-u.ac.jp/faculty/engineering/chair/chem010/manual/accellerase1500_Dupont.pdf (accessed on 16 August 2018).

26. Sendich, E.N.; Laser, M.; Kim, S.; Alizadeh, H.; Laureano-Perez, L.; Dale, B.; Lynd, L. Recent process improvements for ammonia fiber expansion (AFEX) process and resulting reductions in minimum ethanol selling price. Bioresour. Technol. 2008, 99, 8429-8435. [CrossRef] [PubMed]

(c)

(C) 2018 by the authors. Licensee MDPI, Basel, Switzerland. This article is an open access article distributed under the terms and conditions of the Creative Commons Attribution (CC BY) license (http:/ / creativecommons.org/licenses/by/4.0/). 